TAPROBANICA, ISSN 1800-427X. April, 2013. Vol. 05, No. 01: pp. 94-96.

(C) Taprobanica Private Limited, 146, Kendalanda, Homagama, Sri Lanka.

www.taprobanica.org

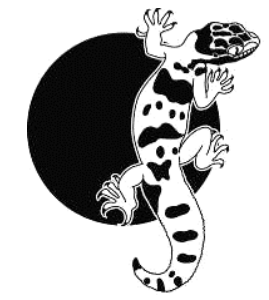

\section{Evidence of Saccolaimus saccolaimus (Chiroptera) roosting in a building in Sri Lanka}

Sri Lanka is a critical area for global biodiversity conservation but rapid land-use changes endanger much of its fauna (Myers et al., 2000; Cincotta et al., 2000). Though understudied and under-estimated, (Hutson et al., 2001; IUCNSL \& MENRSL, 2007), bats are a critical component of Sri Lanka's diversity. Comprising nearly one third of the overall terrestrial mammals of Sri Lanka, bats provide vital ecological and economic services. Sri Lanka has 30 species of bats that belong to 15 genera and seven families (Weerakoon \& Goonatilake, 2006). Emballonuridae (Sheathtailed bats) are widely distributed in the tropical and subtropical regions of the world (Corbet \& Hill, 1980). In Sri Lanka, there are three species of Emballonurids, Saccolaimus saccolaimus (Temminck, 1838), Taphozous longimanus Hardwicke, 1825 and Taphozous melanopogan Temminck, 1845. Phillips (1980) indicates that Saccolaimus saccolaimus, the Naked-rumped Pouched Bat was once common throughout the lowlands of both dry and the wet zones in Sri Lanka but less common in the highlands. However, now this species is considered to be extremely rare and was not recorded in an extensive five year survey conducted by Yapa \& Ratnasooriya (2006) and has been missing from the Sri Lankan bat inventory for 75 years. It was re-discovered in 2011 at an estate in Kurunegala, Wayamba Province roosting in a hollow of a coconut tree (Nanayakkara et al., 2012). The previous record of this species is from Cheddikulam in 1936 (Phillips, 1980; Nanayakkara et al., 2012).

The observation was made on $8^{\text {th }}$ November 2012 inside an abandoned building ( $06^{\circ} 52^{\prime}$ $30.7 ” \mathrm{~N}, 79^{\circ} 55^{\prime} 27.1^{\prime}$ E; alt. $21.3 \mathrm{~m}$ ) in Madiwela, Colombo District, Western Province, Sri Lanka. Relative humidity and the temperature inside the building were $76 \%$ and $29.2^{\circ} \mathrm{C}$ respectively. During the time of observation $(10: 00 \mathrm{~h})$, the building was occupied by two species of bats, a colony of approximately 40 individuals of Hipposideros speoris roosting under the staircase on the ground floor of the building and one Saccolaimus saccolaimus hanging on the wall of the first floor approximately $8 \mathrm{~m}$ above the floor level. It was found clinging in the corner of the wall, with its head down. The bat was captured, measured, photographed and released. Phillips (1980), Bates \& Harrison (1997) and Srinivasulu et al. (2010) were used for field identification (Fig. 1). The same location was inspected again on 29 January \& 15 April 2013. The presence of the bat at different times of the day was recorded during first two visits but not on 15 April 2013.

The individual was an adult male; external measurements are given in Table 1. Figures 1A and $1 \mathrm{~B}$ show details of the head and throat areas. The wings are long, lack a radialmetacarpal pouch and are attached to the ankles. The dorsal pelage is black with small irregular white patches; the ventral pelage is grayish white. Morphological and morphometric characters confirm that the bat is $S$. saccolaimus. On a subsequent visit to the same site 10 weeks later, the bat was found roosting at the same site and there were old bat droppings under the roost. The bat left the roost at about 18:30 hr (RH; 57\%, Temp. $32.8{ }^{\circ} \mathrm{C}$ and atmospheric pressure $1013.2 \mathrm{~h} \mathrm{~Pa}$ ). This is the first confirmed record of this bat roosting in a building in Sri Lanka. Unfortunately this roost site is in danger because the owners of the building could clean up the apartment for reoccupation at any time. On a subsequent visit 23 weeks later, the bat was not recorded at the roost site.

Saccolaimus saccolaimus is known to prefer roosting in hollow trees, especially old, decayed and broken off Kitul palms 
(Caryotaurens sp.) and Arecanut palms (Areca catechu) in Sri Lanka (Phillips, 1980) and four males were found roosting in a hollow of a living coconut tree Cocos nusifera (Nanayakkara et al., 2012). The species may occasionally be found in the roofs of tall buildings (Phillips, 1980) and also in rock crevices (Lekagul \& McNeely, 1977).

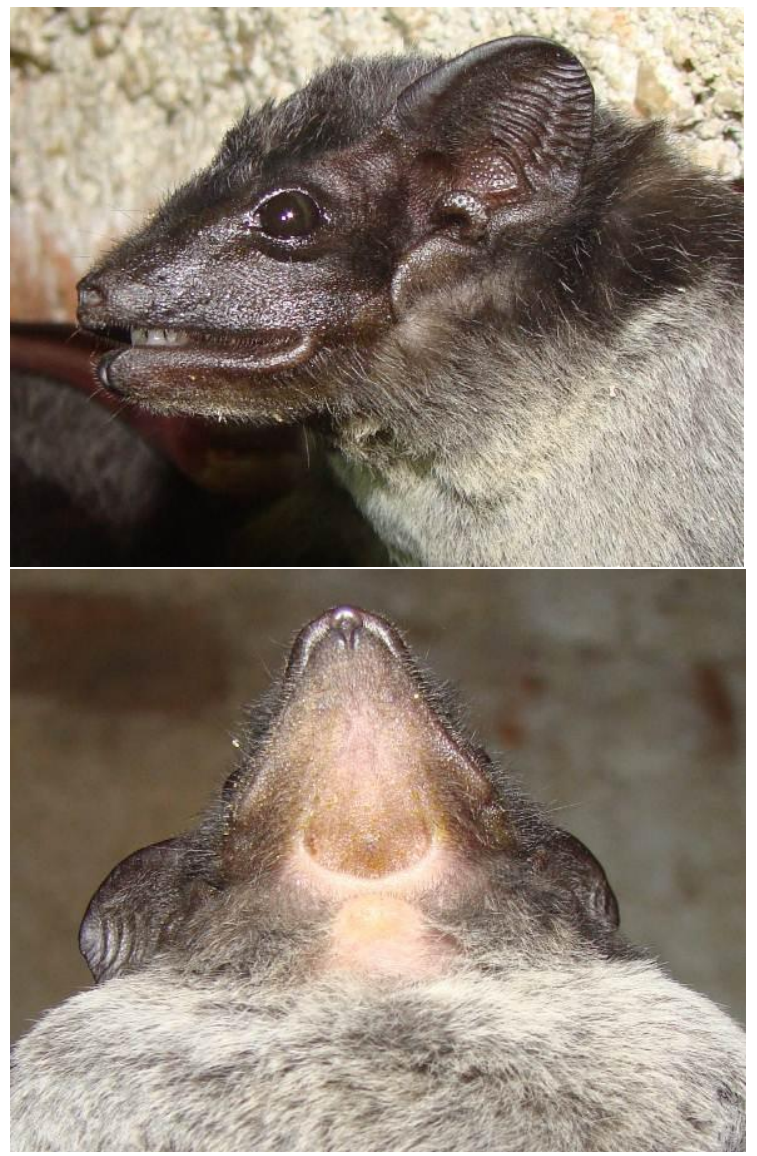

Figure 1: The head of Saccolaimus saccolaimus A, lateral aspect; B, ventral aspect

Our new record is from Madiwela, a town situated in the suburbs of Colombo, Western Province. The previous closest record to Madiwela is Gangodawila (Phillips, 1980). Survey methods can influence which species are found in bat surveys. Mist nets will not necessarily catch high flying species such as Sheath-tailed Bats. The paucity of records could result from difficulties in detecting the species using traditional survey techniques, or the species might be genuinely rare. In recent years, presence/absence information on some species has been obtained using bat detectors. There is potential for using acoustic identification in rapid and efficient surveys of bats in Asian forests (Pottie et al., 2005; Kingston et al., 2003; and Hughes et al, 2011).
Acoustic surveys of bats could be important for evaluation of the distribution and populations of bats especially of tree dwelling and rare species.

The reduction in records of the species could be due to habitat destruction (MOESL, 2012). According to the Red Data List (IUCNSL \& MENRSL, 2007) S. saccolaimus was listed as a Data Deficient (DD) species in Sri Lanka. However recognizing its rarity, the 2012 National Red list considers $S$. saccolaimus as a Critically Endangered (CR) species. IUCN Global Red List put $S$. saccolaimus into Least Concern (LC) Category (Csorba et al., 2008). The species as a whole is still listed as Least Concern globally.

Information on roosting of this bat is urgently needed as this could be the most crucial element in its conservation since the species remains Critically Endangered according to the recent National Red list published by the Ministry of Environment, Sri Lanka in 2012.

What is certain is that we know very little of the distributions and status of this 'rare' bat species. Hence, there is a clear need to undertake a targeted study to better define habitat, distribution, population size, and status, to develop more effective detection techniques and thus assess the conservation status and management requirements of this important species before it is too late.

Table 1: Comparison of published body measurements of Saccolaimus saccolaimus with the described specimen.

\begin{tabular}{l|c|c}
\hline $\begin{array}{l}\text { Measurement } \\
(\mathrm{mm})\end{array}$ & $\begin{array}{c}\text { Bates \& } \\
\text { Harrison, } \\
1997\end{array}$ & $\begin{array}{c}\text { Described } \\
\text { specimen }\end{array}$ \\
\hline Head and body & $80.0-93.0$ & 85 \\
Forearm & $63.0-68.2$ & 70 \\
Tibia & Not available & 29 \\
Hind foot & $12.0-17.0$ & 16 \\
Tail & $21.0-35.0$ & 24 \\
Wingspan & Not available & 425 \\
\hline
\end{tabular}

\section{Acknowledgments}

We would like to thank the two anonymous reviewers for providing valuable comments. Mr. and Mrs. Liyanage are acknowledged for providing hospitality during our visits to their abandoned apartment. And we would like to thank Judith Eger for editing the manuscript. 


\section{Literature cited}

Bates, P. J. J. and D. L. Harrison, 1997. Bats of the Indian Subcontinent. Harrison Zoological Museum Publications, Sevenoaks, UK: 268.

Cincotta R. P., J. Wisnewski and R. Engelman, 2000. Human population in the biodiversity hotspots. Nature, 404: 990-992.

Corbet, G. B. and J. E. Hill, 1980. A World List of Mammalian Species: British Museum of Natural History, London: 226.

Csorba, G., S. Bumrungsri, C. H. Francis, P. Bates, L. Heaney, D. Balate and B. Thomson, 2008. Saccolaimus saccolaimus. In: IUCN 2012. IUCN Red List Of Threatened Species. Version 2012.2. www.iucnredlist.org. Downloaded on $09^{\text {th }}$ November 2012.

Hughes, C. A, C. Satasook, P. J. J. Bates, S. Bumrungsri and G. Jones, 2011. Using echolocation calls to identify Thai bat species: Vespertilionidae, Emballonuridae, Nycteridae and Megadermatidae. Acta Chiropterologica, 13 (2): 447-455.

Hutson, A. M., S. P. Mickleburgh and P. A. Racey, 2001. Microchiropteran bats: global status survey and conservation action plan. IUCN/SSC Chiroptera Specialist Group. Gland, Switzerland: 258 .

IUCNSL \& MENRSL, 2007. The 2007 Red List of Threatened Fauna and Flora of Sri Lanka. Colombo, Sri Lanka: xiii+148.

Kingston, T., C. M. Francis, Z. Akbar and T.H. Kunz, 2003. Species richness in an insectivorous bat assemblage from Malaysia. Journal of Tropical Ecology, 19: 67-79.

Lekagul, B., J. A. McNeely, 1977. Mammals of Thailand. Association for the Conservation of Wildlife, Sahakarnbhat Co., Bangkok: 758 .

MOESL, 2012. The National Red List 2012 of Sri Lanka; Conservation Status of the Fauna and Flora. Ministry of Environment, Colombo, Sri Lanka: viii+476.

Myers, N., R. A. Mittermeier, C. G. Mittermeier, G. A. B. da Fonseca and J. Kent, 2000. Biodiversity hotspots for conservation priorities. Nature, 403: 853-858.
Nanayakkara, R., N. Vishvanath and T. G. T. Kusuminda, 2012. Rediscovery of Pouch bearing sheath-tailed bat Saccolaimus saccolaimus Temminck (Chiroptera: Emballonuridae) from Sri Lanka after 75 years. Asian Journal of Conservation Biology, 1 (2): 134 -137 .

Phillips, W. W. A., 1980. Manual of the Mammals of Sri Lanka - part II $\left(2^{\text {nd }}\right.$ revised edition). Wildlife and Nature Protection Society of Sri Lanka: 267.

Pottie, S. A., D. J. W. Lane, T. Kingston and B. P. Y. -H. Lee. 2005. The micro chiropteran bat fauna of Singapore. Acta Chiropterologica, 7 (2): 237-247.

Srinivasulu, C., P. A. Racey and S. Mistry, 2010. A key to the bats (Mammalia: Chiroptera) of South Asia. Journal of Threatened Taxa, 2 (7): 1001-1076.

Weerakoon, D. K. and W. L. D. P. T. S. de A. Goonatilake, 2006. Taxonomy Status of the Mammals of Sri Lanka. In: Bambaradeniya, C.N.B. (ed.). Fauna of Sri Lanka: Status of Taxonomy, Research and Conservation. IUCN Sri Lanka and Government of Sri Lanka: 216-231.

Yapa, W. B. and W. D. Ratnasooriya, 2006. Ecology and Biology of Sri Lankan Bats. University of Colombo Review: 46-63.

Submitted: 18 Feb 2013, Accepted: 26 April 2012 Sectional Editor: Judith Eger

G. M. Edirisinghe ${ }^{1}$, B. S. A. T. H. Sudasinghe $^{2} \&$ Y. Mapatuna ${ }^{3}$

${ }^{1}$ Wild Rescue Team, 183/6, Colombo Rd, Kesbewa, Sri Lanka

${ }^{2}$ Young Zoologists' Association, Department of National Zoological Gardens, Sri Lanka. E-mail: hsudasinghe@gmail.com

${ }^{3}$ Sustainability Learning Center, No. 228, Kadawatha Road, Dehiwala, Sri Lanka. 